\title{
Veranderingen in samenleving en kerk en de gevolgen voor het beroep van pastor
}

\author{
Gerben Heitink ${ }^{1}$ \\ (Universiteit van Pretoria)
}

\section{ABSTRACT \\ Changes in society and church: consequences for the position of the pastor}

This article is an attempt to open up a new perspective on the crisis of christianity and church in the context of Western Europe, especially The Netherlands. Since half a century the secularisation paradigm has been the dominant perspective to explain this development. But a long-term historical perspective offers a wider horizon. Through the ages there have been different types of christianity (E.Troeltsch): the public church in relation to the civil society, the free church emphasizing church membership (the priesthood of the believers) and the more individualized mystic type of faith. Since the separation of church and state untill totday the second type had been the dominant one. A consequence of the cultural shift from modernity to postmodernity is the rise of "wild devotion' conform the third type of a more individualized way of life. This article pays attention to the challenges of these developments to the practice of church life and the pastoral profession.

Kerk en christendom beleven in West-Europa wellicht de ernstigste crisis sinds de tijd waarin dit werelddeel gekerstend werd. Het totaalbeeld is somber. Kerkverlating en traditieverlies beheersen het denken. Dit raakt ook het beroep van pastor, een samenvattende term waarvoor ik kies omdat hier zowel predikanten als priesters en pastoraal werkenden in de Protestantse en Rooms-Katholieke Kerk onder vallen. Pastores delen in de algehele malaise en missen in toenemende mate een inspirerend toekomstperspectief.

In deze bijdrage wil ik de ernst van deze crisis niet ontkennen, maar ik wil er vanuit een ander perspectief naar kijken. Het secularisatieparadigma dat denkt in termen van verlies en achteruitgang kan gemakkelijk leiden tot blikverenging. Het is naar mijn mening ook mogelijk hoopvoller tegen deze ontwikkelingen

1 Honorêre professor, Departement Praktiese Teologie, Universiteit van Pretoria. 
aan te kijken, wanneer men bereid is deze vanuit een meer historisch perspectief te bezien. Ik zie de genoemde verschijnselen vooral als het gevolg van ingrijpende culturele ontwikkelingen. Wij leven voor mijn besef in een overgangstijd waarin een bepaalde periode in de geschiedenis wordt afgesloten, maar we de toegang tot een nieuwe culturele situatie nog niet gevonden hebben.

Bij het schrijven ben ik me bewust van de grote culturele ongelijktijdigheid in de wereld, waardoor de kerkelijke situatie in het ene werelddeel anders is dan in het andere. Anderzijds kan men ook spreken van een voortgaande globalisering waardoor de Westerse cultuur ook in andere delen van de wereld dominant wordt. Daarom denk ik dat de hier, vanuit de Nederlandse context, beschreven ontwikkelingen voor een deel ook in Zuid Afrika herkenbaar zijn.

In deze bijdrage schets ik eerst een cultuur-historisch perspectief dat dient als referentiekader om de ontwikkeling in kaart te brengen (I). Vervolgens geef ik een beeld van recente ontwikkelingen in kerk en samenleving (II). Tenslotte probeer ik de geschetste ontwikkelingen te betrekken op de toekomst van het pastorale beroep (III).

\section{EEN CULTUUR-HISTORISCH PERSPECTIEF}

In mijn boek 'Biografie van de dominee' (Heitink 2002:15) ben ik uitgegaan van de hypothese dat ontwikkelingen in het beroep van pastor begrepen moeten worden vanuit ontwikkelingen in de kerk en dat ontwikkelingen in de kerk begrepen moeten worden vanuit ontwikkelingen in de samenleving. Deze drieslag levert het raamwerk op voor dit artikel.

De hypothese heeft een grote mate van waarschijnlijkheid, want het is de roeping van de kerk zich voortdurend aan te passen aan nieuwe ontwikkelingen in de samenleving. De vormgeving van het beroep van pastor is één van die antwoorden. Ik gebruik bewust het woord aanpassing omdat dit, althans in protestantse kring, een prikkelend effect heeft. Aanpassing klinkt daar als ontrouw aan de Schrift. Ik wil verdedigen dat er een verschil is tussen aanpassing als adaptatie, accommodatie en assimilatie. Bij het laatste geeft men zijn eigenheid op, maar adaptatie en accommodatie kan men positief waarderen als 'afstemmen op'. Als de kerk zich in de loop der eeuwen niet voortdurend aan nieuwe culturele ontwikkelingen had aangepast, zou ze er wellicht niet meer zijn. Katholieke theologen 
hebben hier vanuit hun visie op de verhouding van natuur en genade wellicht minder moeite mee.

Ik wil proberen in grote lijnen iets van dat historische proces te schetsen om te laten zien dat godsdienst en kerk en dus ook de pastor betrokken zijn in een historisch proces van verandering.

\subsection{Een typologie}

In dit verband wil ik verwijzen naar de sociaal-filosoof en empiricus Ernst Troeltsch (1865-1923), die als een der eersten vanuit een empirisch perspectief naar de kerk gekeken heeft (Fechtner 1995; Molendijk 1996). De opkomende wetenschap van de sociologie bood hiervoor in zijn tijd, begin 20ste eeuw, een instrumentarium. Met hem kan men globaal drie kerktypen onderscheiden.

Het eerste is dat van de publieke kerk, soms ook volkskerk genoemd en in verschillende landen bekend als staatskerk. Het is een kerk die zoveel mogelijk heel de samenleving en alle mensen omvat. Pastor, kerk en samenleving vormen één geheel. Het ambtelijk spreken en sacramentele handelen staan binnen dit kerktype centraal. Deze kerk openbaarde zich vooral in haar hiërarchie en haar liturgie, in basilieken en kathedralen. Vanaf het begin van het Constantijnse tijdperk vormde het Corpus Christianum de dominante kerk- en samenlevingsvorm, met als hart het sacramentele priesterschap waarop ook het protestantse predikantschap is geënt.

Het tweede type is dat van de vrije kerk, gedragen door de leden zelf, een meer besloten gemeenschap, een op zichzelf staand kerkgenootschap of denominatie, een sociaal verband dat zich onderscheidt van zijn omgeving, regels stelt aan lidmaatschap en net als een vereniging onderscheid maakt tussen leden en niet-leden. Troeltsch sprak in dit verband van secte, overigens zonder de negatieve connotaties die het woord meestal oproept. Dit gemeenschapstype hecht grote waarde aan het priesterschap van alle gelovigen en staat vooral bekend als de Familia Dei, het huisgezin van God met de pastor als pater familias.

Het derde type is het mystieke, spirituele of charismatische type, dat de nadruk legt op het individu, op bekering en wedergeboorte. De persoonlijke vroomheid staat voorop en de organisatie en ambtelijke structuur zijn secundair. Eerder manifesteert dit type zich als een beweging. Troeltsch gebruikt hiervoor de woord Kult of mystiek. Binnen dit type is de pastor voor 
alles de charismatische leider of geloofsgetuige die met zijn persoonlijkheid de geloofsgemeenschap profileert. Men kan hier spreken van een beweging waarvoor de geestelijke stromingen van mystiek, pietisme en methodisme de bedding hebben gevormd. Ook kan men zich afvragen of dit type nog wel binnen een kerkelijk verband past of dat een voortgaand proces van subjectiviering uiteindelijk de opheffing van de gemeenschap betekent. Tegenwoordig spreekt men wel van 'wilde devotie' (Stoffels 2002:28-33) als het geheel van verschijnselen waarin dit type zich openbaart. Al in de jaren vijftig van de vorige eeuw stelde de socioloog Schelsky de vraag: Ist die Dauerreflexion institutionalisierbar? (Schelsky 1957:153-174)

Deze typen hebben altijd naast elkaar bestaan. Dat is niet vreemd gelet op het eigen karakter van het christelijk geloof dat aan deze drie typen ten grondslag ligt. Het christelijk geloof kent individuele gestalten, sociale gestalten en publieke gestalten. Individuele gestalten, want Jezus roept mensen op tot bekering en navolging. Sociale gestalten, want het evangelie roept op tot broederschap en zusterschap, binnen de gemeente als lichaam van Christus. Publieke gestalten, want het gaat in het evangelie om de komst van het Rijk van God dat veel breder is dan de kerk en heel de samenleving omvat vanuit de roep om vrede en gerechtigheid.

De reikwijdte van het christelijk geloof strekt zich dus uit van het individuele leven tot het publieke domein. In elk kerktype staat één van deze geloofsgestalten centraal. Maar er is niet alleen sprake van een naast elkaar, ook van een na elkaar. Dat is het historisch perspectief dat ik eerst kort wil schetsen. Mijn referentiekader hierbij is dat van de kerk in de Nederlandse samenleving.

\subsection{De publieke kerk}

Eeuwenlang kende Nederland een publieke kerk, een zekere verwevenheid van kerk en staat. Ook door de Reformatie veranderde dit niet, want meestal gold in die tijd het principe van cuius regio eius religio, waarbij de vorst de religie bepaalde. Sinds Willem van Oranje in 1573 voor het calvinisme koos was de Gereformeerde Kerk in de Nederlanden de heersende of bevoorrechte kerk en werden andere kerken als dissenters tot een schuilkerkbestaan veroordeeld. Nog steeds kan men in Nederland fraaie katholieke schuilkerken bewonderen, zoals 'Ons Lieve Heer op Solder' in Amsterdam. 
Ik spreek van publieke kerk, want Nederland kende geen staats- of volkskerk, daarvoor was de aanhang te gering. Maar iedereen werd gedoopt en kon binnen de kerk een huwelijk aangaan. De predikant vervulde een openbaar ambt in een publieke kerk en was met de ouderlingen belast met de uitoefening van de tucht. Maar omdat de gereformeerde religie met haar nadruk op uitverkiezing zich moeilijk verdroeg met een kerk voor iedereen, werd lange tijd onderscheid gemaakt tussen lidmaten en liefhebbers van de gereformeerde religie. De lidmaten traden toe tot de avondmaalsgemeenschap en stelden zich onder de kerkelijke tucht. De liefhebbers waren meer de zondagse toehoorders, die geloof en kerk een warm hart toedroegen maar geen overtuigde calvinisten waren. De schare liefhebbers was veel groter dan het aantal lidmaten.

Het calvinisme in Nederland is import. De echte calvinisten kwamen uit het Zuiden, zij vormden de kern van de contraremonstranten die het met hun leer van de uitverkiezing op de Dordtse Synode van 1618-19 van de Remonstranten gewonnen hebben. Het Noord-Nederlandse klimaat was veel meer liberaal, in het spoor van de Moderne Devotie en Erasmus, met grote nadruk op de autonomie van het subject.

Door deze ontwikkeling was de katholieke kerk in Nederland lange tijd een kerk zonder priesters en zonder hiërarchie. Slechts af en toe kwam een voortvluchtige priester bij een gemeente de eucharistie bedienen. Later werd het katholicisme gedoogd, maar men bleef burgers op het tweede plan, tot de Franse revolutie. De katholieke kerk was vooral een kerk van leken waarin aanvankelijk vrouwen, de z.g. klopjes als pastorale assistenten een belangrijke rol vervulden. Dat de katholieke kerk in Nederland zich met haar vrije karakter tot voor kort onderscheidde van het katholicisme elders verbind ik met deze ontwikkeling. Pas in 1853 werd de hiërarchie ingevoerd en dat ging niet van harte.

Maar hoe het ook zij, binnen de publieke kerk was de predikant de centrale en dominante figuur en niet voor niets werd hij dominee (heer), genoemd.

\subsection{De verenigingskerk}

Dat beeld verandert heel sterk in de $19^{\text {de }}$ eeuw, niet alleen in Nederland maar ook elders. In de $19^{\text {de }}$ eeuw kwam in veel landen van Europa een scheiding van kerk en staat tot stand. Het 
revolutionaire jaar 1848 heeft hierin een belangrijke rol gespeeld. Er ontstond een heel nieuwe situatie, met een heel ander kerktype. Door de vrijheid van godsdienst kregen niet alleen alle kerken gelijke rechten, ook werd de voormalige publieke kerk een denominatie naast andere kerkgenootschappen.

Belangrijker is dat de kerken in de $19^{\text {de }}$ eeuw uitgroeiden tot een eigen sociaal verband, een gemeenschap die betrekkelijk los kwam te staan van de samenleving. De kerk werd een vereniging, een kerkgenootschap. Ze ontwikkelde een eigen taal, een eigen cultuur en raakte op den duur van grote groepen van de bevolking en van de samenleving vervreemd. De kerk raakte naar binnen gericht. Men noemt dit wel de verkerkelijking van het christendom (Kaufman 1989:6). Zo groeide er langzaam een onderscheid tussen binnen- en buitenkerkelijken. De laatsten, in Nederland tot in de twintigste eeuw een te verwaarlozen minderheid, groeiden langzaam in aantal, tot in onze tijd zelfs zo'n $60 \%$ van de bevolking. Dat betekent dat de kerk vanaf de $19^{\text {de }}$ eeuw heel bewust aan kerstening en evangelisatie moest gaan doen om de mensen buiten de kerk te bereiken en in het publieke domein een rol te blijven spelen op diaconaal en sociaal gebied. Binnen dit kerktype krijgt de pastor een heel andere rol, beter bekend als 'het schaap met vijf poten'.

Door de scheiding van kerk en staat wordt hij om te beginnen verantwoordelijk voor het godsdienstonderwijs op de scholen en de kerkelijke catechese, daarvoor een taak van de schoolmeester. Aan het godsdienstonderwijs wordt grote waarde gehecht. Kennisverwerving en persoonsvorming werden in de $19^{\text {de }}$ eeuw een belangrijke weg naar emancipatie, ook voor vrouwen.

In de $19^{\text {de }}$ eeuw komt ook het individuele pastoraat op, als vrucht van het proces van individualisering, want een mens is meer dan kerkmens. Wanneer we pastoraat onderscheiden in cura generalis en cura specialis, een onderscheid dat teruggaat op Gregorius de Grote ( $6{ }^{\text {de }}$ eeuw), lag vóór die tijd de nadruk op de cura generalis, in de katholieke kerk sacramenteel bepaald, met name door de biecht. Maar door het proces van subjectivering dat sinds de Verlichting om zich heengrijpt, ontstaat er nu vraag naar individuele pastorale zorg op maat. De zorg voor mensen, hun individuele vragen en noden, het bezoek van zieken e.d. Voor die tijd waren er ziekentroosters. In Nederland was de kerkelijke begrafenis eeuwenlang geen taak van de predikant, maar de schoolmeester, tevens koster, voorzanger en voorlezer fungeerde als 
begrafenisdienaar, want lijkpredikaties waren volgens de Dordtse Kerkorde (Art. 65), zijnde 'Roomse stoutigheden', verboden. Aan een begrafenis kwam meestal geen predikant te pas.

Behalve leraar en herder werd de predikant vanaf de $20^{\text {ste }}$ eeuw ook liturg. Een kerkdienst was meer dan alleen een predikbeurt. Nog in de $19^{\text {de }}$ eeuw werd de voordienst verzorgd door de voorlezer en voorzanger, als regel de schoolmeester. Daarna pas kwam de predikant binnen die zich beperkte tot de preek en het grote gebed, meestal zonder enige relatie met de voor zijn binnenkomst gelezen schriftgedeelten. Veel geletterde kerkgangers bezochten alleen dit deel van de dienst.

$\mathrm{Na}$ de Tweede Wereldoorlog wordt de kerkelijke gemeenschap meer en meer een problematische organisatie waardoor de pastor een nieuwe taak krijgt op het gebied van gemeenteopbouw. En in de jongste tijd, nu geloven moeilijker wordt en mensen snakken naar ervaring, spreken we ook wel over de pastor als mystagoog (Firet 1987:68-79), iemand die mensen inwijdt in de geheimenissen van het geloof. Dat is wat we tegenwoordig spiritualiteit noemen.

Zo groeide in deze periode de pastor uit van een betrekkelijk eenvoudig ambt tot een overcomplex beroep. Predicator, leraar, pastor, liturg, agoog, mystagoog, kortom schaap met vijf of zes poten. Nog altijd het dominante type van de dominee, man of vrouw.

Zo zien we dat een andere samenleving als gevolg van de scheiding van kerk en staat leidt tot een ander kerktype en een andere invulling van het predikantschap. Om die gemeenschapskerk in stand te houden moest de pastor steeds meer en steeds nieuwe taken vervullen en de pastoraaltheologie, later praktische theologie genoemd, kreeg er steeds nieuwe vakgebieden bij. Deze nieuwe tak van theologiebeoefening ontstond rond 1800. De katholieke theologie houdt 1774 (Wenen, Rautenstrauch) aan als geboortejaar van de pastoraaltheologie (Müller 1974:42-51), de protestantse theologie houdt het op 1811, het verschijnen van de Kurze Darstellung van Friedrich Schleiermacher $\left(1982^{5}\right)$. Dat laatste is een encyclopedisch werk, waar behoefte aan was gezien de toegenomen differentiatie binnen de theologie met allerlei nieuwe vakgebieden, die allemaal een plaatsje moesten krijgen in het academisch curriculum. Maar door het verdwijnen van de traditionele gemeenschapskerk en het traditionele pastorbeeld zal in de toekomst differentiatie wel eens plaats kunnen gaan maken voor integratie, 
doordat verschillende werkzaamheden in een afgeslankte kerk aan betekenis verliezen en de pastor voor heel andere opgaven komt te staan.

Het tweede kerktype kwam tot grote bloei in de periode 18501960. Er ontstonden hechte kerkelijke gemeenschappen met een grote betrokkenheid van de leden en de predikant als spil van de gemeenschap. Dit kerktype speelde een belangrijke rol in de emancipatie van het katholieke en het gereformeerde volksdeel. In Nederland ziet men vanaf het laatste kwart van de $19^{\text {de }}$ eeuw een emancipatie van de katholieken op gang komen, uitlopend op het Rijke Roomse leven. Overal verrezen nieuwe kerkgebouwen en het aantal roepingen, ook voor orden en nieuwe congregaties, bereikte een hoogtepunt. In protestants Nederland waren met name de Gereformeerde Kerken tot voor kort echte verenigingskerken, vrije kerken van mondige christenen binnen een steeds meer verzuilde samenleving. Onder Abraham Kuyper kozen ze voor een bescheiden kerkelijk instituut en een grote nadruk op de roeping van individuele christenen in de kerstening van staat en maatschappij. Kuyper noemde dit de kerk als organisme. Het instituut kerk kon hij slechts zien als een noodverband op weg naar Christus' koningschap over heel het leven.

\subsection{Overgang naar het derde type}

Ik heb dit tweede type wat uitvoeriger geschetst, want dit is het kerktype waarin de oudere kerkleden, die in onze tijd nog steeds de kerkelijke gemeenschap dragen, zijn opgegroeid. En als we spreken over achteruitgang van de kerk hebben we het met name over de voortgaande teloorgang van dit kerktype. Nederland was nooit zo'n kerkelijk land als in de eeuw die omstreeks 1960 eindigde. De culturele revolutie van de jaren zestig van de vorige eeuw, de gezagscrisis, waarin het gezag van ouders, van opvoeders, van ambtsdragers, van de Schrift en de kerk ter discussie kwam te staan, betekende een radicale breuk met de verenigingskerk, die we nog steeds niet verwerkt hebben. Van de kerk van Christus belijden we dat de poorten der hel haar niet zullen overschaduwen, maar dat zegt nog niets over het wegvallen van historische kerktypen, zoals de verenigingskerk waar in een geïndividualiseerde samenleving nog maar weinig jongeren warm voor lopen.

Vandaar dat ik stelde dat we leven in een overgangsperiode waarin we afscheid nemen van de verenigingskerk maar een goede 
vorm voor een meer geïndividualiseerd kerktype en een andere invulling van het beroep van pastor nog niet gevonden hebben. Voorlopig lijkt het derde type, dat nadruk legt op persoonlijk geloof en overgave aan Jezus, minder onder de crisis te lijden. De evangelische en charismatische beweging zijn gegroeid en kennen veel bloeiende geloofsgemeenschappen. Daarbinnen treedt de predikant op als een charismatisch leider met een persoonlijk geloofsgetuigenis. We kunnen in de traditionele kerken heel wat leren van de wijze waarop men hier aansluiting vindt bij de jeugdcultuur, bijvoorbeeld in de keuze van muziek en liederen.

Het probleem is wel dat veel moderne gelovigen zich hier niet bij thuis voelen omdat zij als kinderen der Verlichting het geloof minder verstaan als blijdschap en zekerheid, maar meer als twijfel en aanvechting, wat ook een heel andere spiritualiteit met zich meebrengt. Zij denken pluraler over het geloof en minder exclusief over de persoon van Jezus. Hoe kunnen in zichzelf gesloten geloofsgemeenschappen van het sociale type een meer open kerk worden, met aandacht voor de belevingswereld van het individu en een dienende rol binnen het publieke domein en hoe zal de pastor er hierbinnen moeten uitzien? Die vraag krijgt dus nu vanuit het geschetste historische perspectief een hoge mate van urgentie.

Dit speelt ook in de katholieke kerk. Minder mensen komen naar de eucharistie, de biecht is vrijwel verdwenen, er is een groot tekort aan priesters en pastoraal werkenden met een andere taakopvatting hebben hun intrede gedaan. Er is met andere woorden na de crisis van de jaren zestig van de vorige eeuw al heel veel veranderd. Maar de vraag is: hoe moet het verder met de kerk en de pastor.

\section{ONTWIKKELINGEN IN KERK EN SAMENLEVING}

Om een toekomstperspectief te kunnen ontwikkelen wil ik opnieuw de aandacht bepalen bij de drieslag van samenleving, kerk en pastor. Welke ontwikkelingen tekenen zich af in de samenleving en wat zijn hiervan de gevolgen voor het kerkelijk leven? Vaak gaan we uit van een containerbegrip als secularisatie, maar dat is zoals gezegd niet nauwkeurig genoeg. Ik schets kort een vijftal ontwikkelingen.

1. Ik noem als eerste het proces van individualisering. Mensen leven minder in gemeenschapsverbanden dan vroeger. Vanuit de veeleisende buitenwereld trekken ze zich terug in hun beschermde privé-wereld. Velen maken zich meer en meer los uit traditionele 
verbanden van familie, buurt, kerk, politieke partijen, verenigingsleven en bepalen zelf hoe ze hun leven vormgeven. Ieder voor zich. Ze maken daarin hun eigen keuzen.

Individualisering heeft grote gevolgen voor de kerk als gemeenschap, met name voor het $19^{\text {de }}$-eeuwse verenigingsmodel. Naarmate mensen individualiseren beleven ze lidmaatschap als knellend en nemen ze afscheid van de kerk. De Samen-opWegkerken, per 1 mei 2004 gefuseerd tot de Protestantse Kerk in Nederland (PKN), verliezen jaarlijks maar liefst $2 \%$ van hun leden, dat zijn er meer dan 60.000. Zo'n zestig grote gemeenten dus. Ook de katholieke kerk verliest veel leden. En dat nu al jaar in jaar uit. En omdat dit proces jongeren heviger raakt dan ouderen, zien we dat de kerk vergrijst. Er treedt geen generatievervanging meer op. Elke volgende generatie is minder kerkelijk dan de vorige, zo blijkt uit recent onderzoek van het kerksociologisch instituut KASKI. De kerken moeten de ernst van deze situatie onder ogen zien.

Dat wil niet zeggen dat mensen die de kerk verlaten ongelovig worden. Het merkwaardige is dat terwijl nog slechts ongeveer $40 \%$ van de bevolking lid van een kerk is, tegelijk meer dan tweederde van de Nederlanders zegt op een op andere manier gelovig te zijn. Geloof en kerk vallen niet langer samen. Dat is natuurlijk een belangrijk gegeven voor pastoraal beleid. Men vindt ook veel geloof buiten de kerk en daar tegenover ook twijfel en ongeloof binnen de kerk. Het 'extra ecclesiam nulla salus' van de kerkvader Cyprianus, dat sinds de derde eeuw heeft gegolden, valt nu moeilijk vol te houden. Anders gezegd: Kerkelijke en buitenkerkelijke mensen gaan volgens onderzoek steeds meer op elkaar lijken (Stoffels 2003:173193).

Dit heeft consequenties voor het kerkmodel. Een kerk die zich alleen richt op haar meelevende leden verschrompelt; een kerk zal zich meer als een open kerk moeten richten op alle mensen in haar omgeving en proberen aan te sluiten bij algemeen menselijke behoeften van zingeving, geborgenheid, educatie en zorg. Dat vraagt enerzijds een concentratie op het individu en anderzijds ook op het publieke domein, om als kerk meer naar buiten te durven treden op de brede markt van religie en levensbeschouwing. Dat heeft consequenties voor het pastor-zijn.

2. Ik noem als tweede het proces van pluralisering. Mensen leven in toenemende mate in verschillende werelden, als gevolg van 
hun opleiding of studie, hun vaak gespecialiseerde banen, de culturele kringen waarin ze zich bewegen, hun hobbies, hun verre reizen. $\mathrm{Ze}$ hebben daardoor ook heel verschillende belevingswerelden. De wereld van de een is niet die van de ander en daardoor zijn mensen zo verschillend dat ze in veel gevallen elkaars taal niet spreken en elkaar daardoor ook weinig te zeggen hebben.

Ook deze pluralisering, heeft grote invloed op de kerk. Dat mensen er heel verschillende belevingswerelden op nahouden, betekent ook dat ze zich op heel verschillende wijze gaan verhouden tot geloof en religie en dat er dus binnen één kerk grote verschillen in geloofsbeleving optreden. De leefwereld van de een ziet er heel anders uit dan die van de ander en dus ziet ook de geloofswereld van de een er anders uit dan van de ander. De kerk is een plurale kerkgemeenschap geworden, de ene waarheid blijkt veelkleuriger dan velen dachten en wie zegt dat verschillende meningen niet tegelijk waar kunnen zijn? Wat waar is voor de een, is nog niet waar voor de ander. Daarom hebben we binnen één gemeente te maken met zoveel hoofden, zoveel zinnen. Dat maakt het geloofsgesprek zo moeilijk. Het geeft spanningen in de kerk. Pluraliteit betekent conflict. De ene mening verdraagt de andere niet. Welke pastor kan zulke heel verschillende belevingen aanspreken?

3. Ik noem als derde het proces van modernisering. Daarmee wordt bedoeld het streven om alle problemen waar we voor staan op te lossen met behulp van de rationaliteit en dat betekent langs wetenschappelijke weg. Denk bijvoorbeeld aan de grote invloed die de economie heeft op de politiek, maar ook de privé-wereld van het individu wordt steeds meer gekoloniseerd (J Habermas) door het economisch denken van 'tijd is geld'. Heel het huishouden bijvoorbeeld is gerationaliseerd met behulp van machines en daardoor verzakelijkt, wat ten koste gaat van de gezelligheid, het als mensen elkaars metgezel zijn. Daardoor wordt de mens autonomer en dus voor eigen besef ook steeds minder van God afhankelijk. Bij modern denken we in de kerk daarom meestal meteen aan vrijzinnig. Modernisering heeft voor velen het geloof in Gods voorzienigheid tot in de kern aangetast.

Ook modernisering als derde heeft grote invloed op kerk en geloof. De rationaliteit heeft ook de kerk veroverd via een bedrijfsmatige organisatie en een groeiende bureaucratie. Ook het ambt van predikant wordt door velen opgevat als een baan, liefst van negen tot vijf. 
Maar niet alleen de organisatie moderniseert, ook het geloof moderniseert. Veel gelovigen zijn, wat we noemen door de Verlichting heengegaan. Van de naoorlogse generatie van de 'babyboomers' hebben velen afgehaakt (Van der Meulen 2003:5168; Heitink 2003:173-193). Ze voelden zich door de kerk bedrogen, door het geloof in God voor de gek gehouden, door hun christelijke opvoeding onvrij gemaakt. En wie het geloof behouden hebben, hebben in toenemende mate vragen en twijfels. Zekerheden hebben plaats gemaakt voor aarzelingen. Moderne mensen hebben niet veel op met dogma's en vastgestelde geloofsbelijdenissen. Dat is hun te machtig, te verheven, ze kunnen er niet bij. Dit stelt nieuwe eisen aan geloofsopvoeding, catechese en pastoraat en vraagt van predikanten meer specialistische kennis.

4. Ik noem als vierde het proces van mobilisering. Mensen zijn mobiel geworden. Ze verplaatsen zich met hun auto over grote afstanden, brengen een deel van hun leven door in hun tweede huis in het buitenland of overwinteren in warme streken, waar ze hun eigen kerkelijk leven organiseren. Dat heeft een ontbindend effect op gemeenschapsverbanden in de eigen omgeving, de buurt, de kerk. De nabije gemeenschap maakt plaats voor een netwerk van vrienden en relaties op afstand, wereldwijd maar via de e-mail onder handbereik. Er ontstaat een virtuele gemeenschap der heiligen als nieuwe gestalte van de onzichtbare kerk.

Ook mobilisering heeft dus grote invloed op de kerk. Denk bijvoorbeeld aan de zondagse kerkgang. Gemeenteleden zullen veel minder frequent de diensten in de eigen gemeente bezoeken dan vroeger. Ze worden meer gelegenheidskerkgangers. Vergaderingen zullen door minder mensen tegelijk bezocht worden.

Houdt de kerk daar rekening mee? In de kerkdiensten werken we met leesroosters. Dit veronderstelt continuïteit van week tot week via de doorlopende lezing. Maar gelegenheidskerkgangers komen voor 'de kick'. Ze moeten op dit moment geraakt worden, aangesproken. Dat veronderstelt een andere orde van dienst en wellicht ook een ander soort prediking of een speciaal charisma van de voorganger om mensen te kunnen inspireren. Gelegenheidsdiensten bij doop, huwelijk en uitvaart zijn veel beter op de beleving van gelegenheidskerkgangers ingesteld en trekken meer buitenstaanders. 
5. Ik noem als vijfde het proces van intensivering van het leven, met name door de prestatiedwang, de opgevoerde werkdruk, de consumptiedwang door het aanschaffen van nieuwe gebruiksgoederen en de stress die dit alles met zich meebrengt, vooral in een gezin waar zowel vader als moeder een volledige en drukke baan hebben. Dan heeft een mens het weekend hard nodig om op adem te komen. We kennen natuurlijk ook de bijwerkingen zoals stress, overspannenheid, relatieproblemen, opvoedingsproblemen, depressies, burn out. We rennen onszelf voorbij en bepalen daarvoor een hoge prijs.

Ook de intensivering van het leven heeft invloed op de kerk. Mensen hebben het door de week zo druk dat ze het weekend hard nodig hebben om bij te komen en eindelijk aan elkaar en hun gezin toe te komen. Dan schiet de kerkdienst erbij in. Ook vergaderingen door de week vormen een belasting en een kerkelijke functie al helemaal. Je krijgt mensen wel voor kortlopende projecten. Velen willen zich voor een bepaald project best een paar maanden inzetten, maar vraag hen niet voor een periode van vier jaar. Dat is onoverzienbaar. Pastores hebben daardoor minder ervaren kader om zich heen en moeten meer zelf doen, waardoor de vrijwilligerskerk het lijkt te begeven.

Samenvattend moet ik concluderen dat culturele ontwikkelingen grote invloed hebben op ontwikkelingen in de kerk, zowel in haar organisatie als op de wijze waarop mensen al dan niet geloven. Een andere samenleving vraagt een andere kerk en dus ook een andere invulling van het beroep van pastor. Maar hoe zal dat er uitzien?

\section{DE PASTOR VAN DE TOEKOMST}

De kern van het pastorale beroep zal door dit alles niet wezenlijk veranderen. De pastor is immers theoloog, nauwkeuriger gezegd hermeneut, dat wil zeggen vertaler en vertolker van het evangelie binnen de leefwereld van uiteenlopende groepen mensen. Hij of zij heeft een dubbele taak, enerzijds de toerusting van de vaak kleine kernen van gemeenteleden, belijdende christenen die vanuit het evangelie gevoed willen worden om deel te kunnen nemen aan de dienst van het evangelie in hun gemeente, anderzijds aansluiting zoeken bij de uiteenlopende behoeften van mensen buiten de kerk.

Kleine kerkelijke gemeenten zullen in toenemende mate vrijwilligerskerken worden, die door de groep zelf gedragen worden. 
Pastores zullen gemeenteleden coachen om pastoraal werk te doen, kringen te leiden en voor te gaan in de liturgie. Het uitvoerende werk wordt meer een zaak van gemeenteleden zelf, waarbij pastores werkzaam zijn in de tweede lijn, bezig met de toerusting van gemeenteleden.

Dat kan moeilijk anders, want er zullen minder pastores zijn, althans minder fulltime werkzame pastores, want de financiële draagkracht van gemeenten wordt zwakker en een pastor is niet alleen een zegen voor de gemeente maar ook een zware kostenpost. Het aantal deeltijdpastores neemt nu al toe en een aantal van hen is daarnaast werkzaam in een maatschappelijke functie. Sommigen zien dat ook als een voordeel omdat het wereldje van de kerk hun te klein en te geïsoleerd wordt om een volwaardige leefwereld te kunnen creëren. Zij willen hun vleugels breder uitslaan. In grote delen van de wereld, bijvoorbeeld in Afrika, is dat overigens heel normaal. Men spreekt daar van een tentmakersbediening (tentmaking ministry), naar het voorbeeld van Paulus.

Het betekent ook schaalvergroting. Pastores zullen minder aan één kleine gemeente verbonden zijn waarin ze alle taken van een pastor uitoefenen. En kleine gemeenten zullen ook zelf opgaan in grotere verbanden willen ze volop kerk kunnen zijn. Naast territoriale gemeenschappen, van mensen die in een zelfde plaats of buurt wonen, zullen er meer mentale en categoriale geloofsgemeenschappen ontstaan, die zich profileren op een bepaalde geloofsbeleving, of die zich richten op een bepaalde categorie van deelnemers, bijvoorbeeld jongeren. $\mathrm{Nu}$ al zien we hier en daar spontaan jeugdkerken ontstaan. Ontwikkelingen als pluralisering werken hierin door.

Pastores zullen zich gezien de ingewikkeldheid van allerlei vormen van geloofscommunicatie meer moeten gaan specialiseren, bijvoorbeeld in de richting van jongerenwerk, of pastoraat, of gemeenteopbouw, of missionair werk. De geschetste ontwikkelingen stellen eisen aan de kwaliteit van het werk. De tijd van de alleskunner en daarmee van de pastor als solist is voorbij. Werken in teamverband heeft de toekomst. Collegialiteit oefenen is in toenemende mate een belangrijk leerdoel in de opleiding van pastores.

Naarmate het voor mensen niet meer vanzelfsprekend is om mee te doen in de kerk en we te maken krijgen met heel 
uiteenlopende vormen van kerkelijke betrokkenheid, zal het aanbod in toenemende mate de vraag bepalen. Mensen kiezen voor een pastor die hen aanspreekt, laten door haar of hem hun relatie bevestigen, hun kind dopen, bezoeken daar de diensten of nemen deel aan een kring. Ook veel buitenkerkelijken kiezen voor een kerkelijke uitvaart. Dit zijn ontwikkelingen die we overal in de samenleving zien, in de kerk zal dat niet anders zijn. Het zijn diensten waarvoor mensen van buiten ook graag willen betalen, niet als vaste vrijwillige bijdrage maar bijvoorbeeld per cursus of voor een viering. Dat is iets waar veel kerken nu nog vreemd tegenaan kijken. Naast inkomsten uit lidmaatschap zullen zij ook nieuwe inkomstenbronnen uit religieuze dienstverlening en sponsoring door 'liefhebbers' moeten creëren. Het laatste is minder vreemd dan het lijkt, want een sponsor is vanouds een doopgetuige.

Ik sprak van een dubbele taak, een dubbelstrategie, een term van Ernst Henau (2002), die in deze ontwikkeling zichtbaar wordt. Naarmate het kerklidmaatschap afneemt en de aandacht voor geloof en levensbeschouwing, voor symbolen en rituelen, voor zingeving en religie, zich meer afspeelt buiten de kerk, beseffen pastores dat ze er niet alleen zijn voor kerkleden maar ook voor mensen buiten de kerk. Ze zullen meer contacten krijgen met buitenstaanders en inspelen op hun behoeften. Dat geeft een nieuwe dimensie aan de missionaire opdracht van de kerk.

$\mathrm{Er}$ is in een anoniemer wordende samenleving een groeiende behoefte om ergens bij te horen, een behoefte aan zingeving, een behoefte aan informatie over geloof, religie en moraal, een behoefte aan ritualisering op hoogte- en dieptepunten van het leven, een behoefte aan uiteenlopende vormen van hulp. Beschikbaarheid en gastvrijheid zullen kerken hoog in het vaandel dragen en predikanten zullen haar hierin voorgaan. Momenteel ziet men hoe steeds meer gemeenten zich profileren als een open en gastvrije kerk (Hendriks 1999; Heitink 2003 ${ }^{\mathrm{a}}$ 173-193). Er zijn zelfs gemeenten die hun zondagse diensten heel laagdrempelig maken, gericht op buitenstaanders en die de vertolking van het evangelie voor de gelovigen verplaatsen naar een doordeweekse avond, in de vorm van samenkomsten van een huisgemeente (de Willow Creek-formule).

Uiteraard gaat het hier om een spanningsvol gegeven, want hoe kan men de toerusting van de gelovigen combineren met openheid voor buitenstaanders, of anders gezegd: Hoe verbindt men identiteit met pluraliteit? De vraag stellen is haar beantwoorden. 
Naarmate gemeenten een duidelijke identiteit kennen en zich daarop profileren, blijken ze een grotere aantrekkingskracht te hebben op hun omgeving. Want pluraliteit in beleving roept de behoefte op aan identiteit om duidelijk maken wat men gelooft en waar men voor staat. In toenemende mate is de predikant de belichaming van die kerk en het gezicht van de gemeente.

Er verandert veel en er zal de komende decennia nog veel meer veranderen en dat is nodig willen we de overgang kunnen maken van een gemeenschapskerk naar een netwerkachtige meer geïndividualiseerde kerkgemeenschap. Het zijn ontwikkelingen waar we nu misschien nog vreemd tegenaan kijken, want de traditionele kerk en de bekende invulling van het predikantschap komen erdoor op de helling te staan. Maar we moeten hierbij bedenken dat deze toekomst op veel plaatsen nu al begonnen is. Bedenk ook dat veel predikanten nu al volledig werkzaam zijn buiten de kerk in de geestelijke verzorging binnen de gezondheidszorg, de krijgsmacht, bij justitie, in geestelijke begeleiding of in andere maatschappelijke verbanden van hulpverlening en vanuit adviesbureaus. Dat zijn allemaal gespecialiseerde functies. Bedenk dat vroegere taken van de kerk nu al zijn overgenomen door het onderwijs of het sociaal werk, door andere levensbeschouwelijke instellingen of seculiere ritualisten.

De kerk beweegt zich op een veel bredere religieuze en levensbeschouwelijke markt dan voorheen. Door velen wordt ze nog gezien als marktleider, maar net als de marktleider onder de supermarkten (in Nederland Albert Heijn), kan ze maar zo tot de ontdekking komen dat haar aanbod te exclusief geworden is en anderen ongemerkt grote stukken van die markt veroverd hebben en dat het nu weer tijd wordt om 'op de kleintjes te letten' (aldus de reclameformule van dit bedrijf).

Door deze ontwikkeling komt de kerk weer thuis, namelijk daar waar zij twee millennia geleden begonnen is: Mensen geroepen tot navolging door Jezus zelf, uitgezonden in een niet-christelijke wereld, levend vanuit hun geloof en dienstbaar aan anderen. Een nachristelijke tijd als de onze houdt ook in dat veel leerstellige en kerkelijke ballast is weggevallen en we op een nieuwe wijze ons geloof mogen beleven. Dat zal mede het pastorbeeld van de toekomst bepalen. 


\section{Literatuur}

Fechtner, K 1995. Volkskirche im neuzeitlichen Christentum. Die Bedeutung Ernst Troeltschs für eine künftige praktisch-theologische Theorie der Kirche. Gütersloh: Gütersloher Verlag-Haus.

Firet, J 1987. Spreken als een leerling, Kampen: Kok.

Heitink, G 2002². Biografie van de dominee. Baarn: Ten Have.

-, 2003. Tussen 'oprit 57' en 'afslag 03', de weg, het landschap en de praktische theologie. Amsterdam: VU.-uitgeverij.

-, 2003 $3^{\mathrm{a}}$ Van buiten naar binnen denken. Op zoek naar een open kerk, in: Heitink, G. en Stoffels, H.C. (red.), Niet zo 'n kerkganger. Zicht op buitenkerkelijk geloven, 173-193. Baarn: Ten Have

Henau, E 2002. Kerk in de kering. Christelijke gemeenschapsopbouw in een mobiele samenleving. Nijmegen: KUN.

Hendriks, J 1999. Gemeente als herberg. De kerk van 2000 - een concrete utopie. Kampen:.

Kaufmann, F X, Religion und Modernität. Tübingen: Mohr-Siebeck.

Molendijk, A L 1996. Zwischen Theologie und Soziologie. Ernst Troeltschs Typen der christlichen Gemeinschaftsbildung: Kirche, Sekte, Mystik. Gütersloh: Gütersloher Verlag.

Müller, J 1974. Die Pastoraltheologie innerhalb des theologischen Gesamtkonzepts von Stephan Rautenstrauch (1774), in: Klostermann, F. en Zerfass, R. (Hg.), Praktische Theologie heute, 42-51. München: Kaiser.

Schelsky, H 1957. Ist die Dauerreflexion institutionalisierbar? In: Zeitschrift für Evangelische Ethik 1, 153-176.

Schleiermacher, F $1982^{5}$ (1811). Kurze Darstellung des Theologischen Studiums zum Behuf einleitender Vorlesungen. Darmstadt: Wissenschaftliche Buchgesellschaft.

Stoffels, H C 2002. 'Wilde devotie' als doe-het-zelfreligie: een terreinverkenning, in: Barnard, M. en Schuman, N, Nieuwe wegen in de liturgie, 28-33. Zoetermeer: Meinema.

-, 2003. Opkomst en ondergang van de buitenkerkelijke. Enige historische ontwikkelingen, in: Heitink, G en Stoffels, H C (red.), Niet zo 'n kerkganger. Zicht op buitenkerkelijk geloven, 11-26.

Van der Meulen, M 2003. Waarom babyboomers de kerk verlieten, in: Heitink, $\mathrm{G}$ en Stoffels, H C (red.), Niet zo 'n kerkganger. Zicht op buitenkerkelijk geloven, 51-68. 